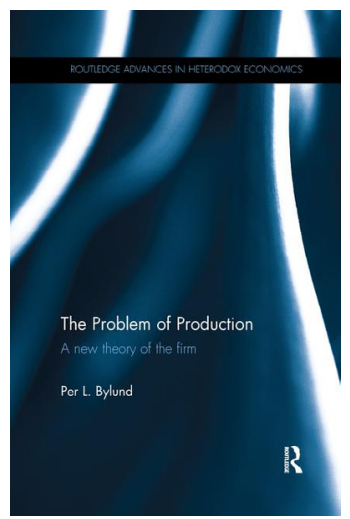

\title{
The Firm Beyond The Market
}

\section{Duygu Phillips}

Oklahoma State University, Stillwater, Oklahoma, United States

\section{Shawn Jones}

Oklahoma State University, Stillwater, Oklahoma, United States

BYLUND, Per L. The problem of production: a new theory of the firm. Londres: Routledge, 2015. 194p.

Why does a firm exist? Machlup (1967) elaborated on the age old argument of which theory of the firm was correct, and highlighted that each theory targets a very specific subset of what the firm is. He concluded that "the choice of the theory has to depend on the problem we have to solve" (p. 30-31). This view is still true today, with one of the key shortcomings we see in the literature being that while many theories of the firm explain some aspects of the creation of the firm, none truly explains the problem of why the firm exists in the first place.

Marshall's Principle of Economics (1961) defined the firm as a profit maximizer, which built the roots for the neoclassical view of the firm. Coase's seminal article The Nature of the Firm (1937) proposed transaction costs as the key determinants of the theory of the firm, which Williamson (1979) elaborated on further. Since Coase, several aspects of the theory of the firm were developed, including the strategic theory of the firm (RUMELT; LAMB, 1997), the behavioral theory of the firm (CYERT; MARCH, 1963), and knowledge based theory of the firm (GRANT, 1996), among others.

Bylund, in his book The Problem of Production (2015), proposes a new theory of the firm with an even more profound definition than what existing theories of the firm have previously suggested. The firm, according to Bylund, is an "island of specialization" (p. 84), emerging

DOI https://doi.org/10.30800/mises.2019.v7.1243

* Duygu Phillips is a third year Ph.D. student in Entrepreneurship at Oklahoma State University.

Email: duygu.phillips@oakstate.edu

** Shawn Jones is a third year Ph.D. student in Entrepreneurship at Oklahoma State University.

Email: shawn.jones10@oakstate.edu 
outside the current extent of the market as an outcome of entrepreneurial undertaking and as a solution to "specialization deadlock" (p. 65) within the market by innovating, and in turn expanding the extent of the market. "Specialization deadlock" occurs when "the divisions of labor and capital engender a path-dependent development that is limited to gradual changes and adaptive responses to exogenous change" (BYLUND, 2015, p. 65). While existing theories of the firm aim at answering 'why' the firm exists, 'what' the firm is, and 'how' it exists, the new theory of the firm presented in this book focuses on 'what' the economic function of the firm is, which leads to why it exists at all and how it emerges.

Bylund makes several critical contribu-tions, one of which is to bring more clarity to the definition of the firm based on its economic function. What is, then, the economic function of the firm? The economic function of the firm, according to Bylund, is to solve the problem of production that is embodied in the concept of the specialization deadlock by being an island of specialization. Placing the firm as a solution to specialization deadlock explains why the firm exists, which is a key contribution to what we see as a shortcoming in the literature.

Bylund (2015) states the firm as an outcome of the implementation of novel and innovative production through means not currently available in the market (p. 97-98). A firm within the market may be able to marginally increase productivity or streamline processes by virtue of the price mechanism, but it cannot create anything truly new. As Schumpeter (2017) argues in The Theory of Economic Development, novel products are created by new firms that do not already exist in the market. To create something new requires the firm to step outside the existing boundary conditions imposed by the market. This argument is elaborated with an extensive look at the very nature of what the firm is, which is creatively defined as an 'island of specialization'. In other words, the market can overcome the economic problem of limited specialization within the market by utilizing innovative firm emerging outside the existing market.

Specialization, being the driver of productivity increases in Bylund's model, is showcased as the critical component for the existence of the firm. Bylund highlights Adam Smith's (1776) pin factory as an example in which specialization of tasks allows for the increased production of pins over nonspecialized pin producers. As the pin is subdivided, products in the market become further subdivided to increase productivity. This subdivision falls prey to the concept of the incomplete good. The value of an unfinished good is nonexistent to the end user, and the unfinished good only has value to those that create subsequent goods from it. The new level of specialization presents an issue since the novelty produced from an unfinished good may or may not be viable in the market. In order for a firm to enter the market, the value of this new specialization has to be higher than the existing methods of producing the novel good. Should the cost of the new specialization be too high or should the novel good not fit within the existing market, the firm will be unable to sell that good and subsequently fail to enter the market. In short, the problem the market faces is one where a firm with a new idea or specialization cannot come into existence within the constraints of the market as the market has no means of properly pricing the new idea until it has come to fruition and turned into a product the market can either purchase or sell.

The emergence of the firm outside the market is not without its costs. In bringing novel ways of production and new specializations to the market, the firm must overcome several 
difficulties such as acquiring financial capital, surviving further competition, and resisting absorption by the market. Even though the existing market production also requires some capital investment, the firm looking to bring about an innovation must also bear uncertainty. Moreover, the required time until the returns are achieved is longer than the market production, further adding to the level of uncertainty and to risk.

Bylund does a masterful job of reducing the idea of the firm to its most basic purpose, to be an agent of production. The firm plays a central role in the development of an economy by means of entrepreneurial action. This is supported by both Austrian economics and entrepreneurship theories. However, what is different in Bylund's new theory of the firm is that the firm "ends with market-making" (BYLUND, 2015, p. 140), as the competition increases in the extended market. Defined as an institution with a specific economic function, the firm is argued to facilitate the expansion of the extent of the market, as well as the increased specialization in the market. While this argument makes perfect sense, it also generates a paradox: as the firm expands the extent of the market, it is argued to shorten its own lifecycle once it enters the market. One important follow up question would be to determine strategies that help the firm endures this threat of getting absorbed by the market as the competitors appear and the innovation becomes a commodity.

The concept of the firm as described by Bylund fits quite well with the current literature in the field of entrepreneurship. By generating all three types of entrepreneurship within the market process, innovation solves the problem of production by equilibrating, disequilibrating, and kaleidoscopic outcomes. Entrepreneurial action with the goal of offering a novelty to the society to satisfy the needs and wants of the customers can equilibrate or disequilibrate the market. The entrepreneur accepts the risk associated with the creation and implementation of a new idea in order to create a firm. The Schumpeterian (2017) disequilibrating entrepreneur, who brings something completely new to the world, would have to step outside of the market to create the firm as there would be no customers for his/her novel goods and thus no market for the firm to exist within. Schumpeter defines the producer as an initiator of economic change within the economic development process including new goods, new quality of goods, new production methods untested by the market, new markets, or new raw materials, or new organizations of industry, which are the domain of the entrepreneur. (SCHUMPETER, 2017) In line with this definition, Bylund's framework presents the new firm as an actor that changes the market through new specialization, and the entrepreneur as the backbone of economic development. Should the new island of specialization created by the entrepreneur be successful, the market would expand to encompass the new firm. Should it fail, it would not have much of an effect at all and the market would remain unchanged. As with Bylund's view of the firm, a firm that is unsuccessful will simply not join the market.

The Kirznerian (1973) equilibrating entrepreneur, one who discovers new opportunities within a market is also supported by this view of the firm. Kirzner argues that the existence of economic error leads to the divergence of prices which create opportunities for entrepreneurs to correct the error and bridge the gap in the market. "At each instant, because the market is in a state of disequilibrium, genuine allocative inefficiencies remain yet to be removed simply because entrepreneurs have not yet noticed the profit opportunities represented by these inefficiencies" (KIRZNER, 1978, p. 74). In this case, the sub specialization of an existing 
good, which is an allocative inefficiency in this case, in the market would also force the firm to emerge outside the market, as while there are preceding goods and a market for the final good, the new system used by the firm which creates that good is untested. The new process used by the Kirznerian entrepreneur in this case may or may not create the desired result and thus still falls prey to the whims of the market. If the new process is better than the existing methods, it will enlarge the market and the firm will then join the market. If the process fails, the firm will fail to join the market, and thus the market will remain unchanged.

The firm is the natural outcome of entrepreneurial action, rather than the means of the market. It is an outcome of the implementation of novel and innovative production that cannot be realized through means currently available in the market. This view of the firm is in stark contrast to the initial traditional views of the firm based on Coase, who "assets that the firm is a formal organization that is based on the concept of authority, which supersedes the market's price mechanism and therefore is distinct from market coordination." (BYLUND, 2015, p. 97). While Coase's firm exists outside the market as well, Bylund's firm neither requires it to be a formal organization based on the concept of authority, nor does it supersede the price mechanism of the market. On the contrary, Bylund's firm is dependent on the market's price mechanism for its very existence. While according to Bylund's theory, the price mechanism of the market does not work within the firm, the firm as a whole is still quite reliant on the market for the final product, even where the firm's final product is merely a subcomponent of a larger product.

Overall, The Problem of Production offers a well-developed theory of the firm and an advancing perspective on the nature of the market as a whole. By identifying the firm as the end result of specialization, Bylund creates a solid new theory of the firm which focuses on the economic function of the firm, by answering the question of why the firm exists at all. By focusing on the economic function of the firm and how the firm fits within a larger market, Bylund bridges the gaps between a pre firm market, firm creation, and the firm entering the market. After all, without a market the firm has no reason to exist. Through the in-depth elaboration of the function of the market, beginning with the creation of money itself (MENGER, 1892; MISES, 1949), Bylund creates a step by step view of the way firms are created in the real world. The new theory of the firm explains how firms affect the market as well as how they are affected by the market. As Bylund's firm ends with market making, there exists a gap within the book where companies already in the market can survive and create new products. One possible solution would be to examine how a company can straddle the line of being outside the market while also being within the market. Future research can look into how firms can resist the market absorption while introducing innovation and expanding the market. Therefore, the next question could be how can innovation strengthen firms within the extent of the market? Put differently, how can innovative firms resist specialization deadlock within the market? After all, there are innovative companies, such as Apple, creating disruption (the Iphone for example) while within the market. One additional question which can be posed is: Can the firm emerge outside the extent of the market and survive within the market without innovation? In other words, is it possible for a firm to survive long-term within the extent of the market while being beset by innovative firms from outside the market? We believe this could be an opportunity as well as a challenge for the future theory of the firm. 


\section{References}

BYLUND, Per L. The Problem of Production: A new theory of the firm. Londres: Routledge, 2015.

COASE, Ronald Harry. The nature of the firm. Economica, v. 4, n. 16, p. 386-405, 1937.

CYERT, Richard. M.; MARCH, James. G. A behavioral theory of the firm. Englewood Cliffs: Prentice Hall, 1963.

GRANT, Robert. M. Toward a knowledge-based theory of the firm. Strategic Management Journal, v. 17, n. S2, p.109-122, 1996.

KIRZNER, Israel. M., Competition and Entrepreneurship. Chicago: University of Chicago Press, 1973.

KIRZNER, Israel. M. Economics and error. New directions in Austrian economics. Kansas City: Sheed Andrews and McMeel, Inc., 1978.

MACHLUP, Fritz. Theories of the Firm: Marginalist, Behavioral, Managerial. American Economic Review, v. 57, n. 1, p. 1-33, 1967.

MARSHAL, Alfred. Principles of Economics: Text. London: New York: Macmillan for the Royal Economic Society, 1961.

MENGER, Carl. On the origin of money. Economic Journal, v. 2, n. 6, p. 239-55, 1892.

RUMELT, Richard. P.; LAMB, R. Towards a strategic theory of the firm. Resources, firms, and strategies: A reader in the resource-based perspective. Londres: Oxford, 1997.

SCHUMPETER, Joseph. A., The Theory of Economic Development. Londres: Routledge, 2017.

SMITH, A. An Inquiry into the Nature and Causes of the Wealth of Nations. Cannan: Online Library of Liberty, 1776.

MISES, Ludwig Von. Human action: A treatise on economics. Washington: H. Regnery Company, 1949.

WILLIAMSON, Oliver E. Transaction-Cost Economics: The Governance of Contractual Relations. Journal of Law and Economics, v. 22, n. 2, p. 3-61, 1979.

ReCEIVEd DATE: SeT 152019

ACCEPTED DATE: SET 292019 